\title{
Assessment of Knowledge and Attitude towards COVID-19 Vaccination among People in Selected Community of West Bengal
}

\author{
Aditi Karmakar \\ Clinical Instructor, College of Nursing, Medical College and Hospital, Kolkata, W.B.
}

\begin{abstract}
Several Coronaviruses have caused serious problems in humans. In early March, 2020, the World Health Organization (WHO) declared that the Corona Virus disease 2019 (COVID-19) is a global pandemic. COVID-19 is a new strain of coronavirus and scientists are still collecting information and conducting research on the virus. Vaccination is the most effective strategy to protect the population from COVID-19 infection and several vaccines have been approved against the disease globally. But, the knowledge and attitude towards COVID-19 vaccination among general community people are very poorly understood. Thus, the present study aimed to investigate the knowledge and attitude towards COVID-19 vaccination among selected community people in West Bengal and it is observed that $66.75 \%$ people had moderate knowledge and $98.25 \%$ people had high attitude towards COVID-19 vaccination.
\end{abstract}

Key Words: Corona Virus disease 2019

(COVID-19), Vaccination, Knowledge and

Attitude, community people

\section{INTRODUCTION}

Corona Virus disease 2019 (COVID-

19 ) is a deadly disease which affects many countries in the world. The disease is caused by new strain of Corona Virus, SARSCOV-2 which have become a serious problem worldwide ${ }^{[1]}$.

The World Health Organization (WHO) declare the COVID-19 outbreak as a pandemic on $11^{\text {th }}$ March, $2020^{\text {[2] }}$.

During the time of writing $\left(10^{\text {th }}\right.$ November) this pandemic has affected 224 countries with 251.75 million confirmed cases. It causes death of 50.83 million people whereas 227.92 million people recovered from this deadly disease globally [3].

The incidence of the disease is higher in USA with 47.53 million of confirm cases, 7.78 million of death and 37.60 million of recovered cases, whereas in India the total cases are 34.38 million with 4.61 million deaths and 33.77 million recovered cases ${ }^{[3]}$.

The first case of COVID -19 infection in India was reported from Kerala on $27^{\text {th }}$ January $2020^{[4]}$.

Vaccination is the most important public health measure and most effective strategy to protect the population from COVID-19 infection since SARS-COV-2 is a highly contagious virus affecting population widely and globally ${ }^{[5]}$.

Among WHO approved 8 nos. of covid -19 vaccines, 6 nos. of vaccines are available in India. But 'Covishield' and 'Covaxin' are widely used in India. In India total 35.6 crore people (25.8\%) are fully vaccinated ${ }^{[6,7]}$.

In West Bengal, a total of 19280 cases of death were recorded out of $16.01,586$ covid confirm cases. At the same time, 83266658 doses of vaccination had already been completed ${ }^{[8]}$.

\section{Need of the study:}

A global survey about the acceptance of potential COVID-19 vaccine showed that about $48 \%$ of population are 
Aditi Karmakar. Assessment of knowledge and attitude towards COVID-19 vaccination among people in selected community of West Bengal.

confused about this vaccine and remained unaware whether they have the vaccination [9]

Similarly, another study in China showed that only $54 \%$ of their populations were intended for vaccination. Above two studies showed that very low proportion of population are intended to vaccinate themselves ${ }^{[10]}$.

\section{Statement of the problem:}

Assessment of knowledge and attitude towards COVID-19 vaccination among the people in selected community of West Bengal.

\section{Objective of the study:}

1. To assess the knowledge and attitude towards COVID-19 vaccination among the people residing in around Dharmada Gram Panchayet, Nadia, West Bengal.

2. To determine the relationship between knowledge and attitude towards COVID -19 vaccination and selected demographic variables.

\section{Research hypothesis:}

H1: There will be significant relationship between knowledge and attitude of people towards COVID-19 vaccination.

H2: There will be significant relationship between demographic variables and knowledge and attitude of people.

\section{Assumptions of the study:}

1. Community people will have some knowledge regarding COVID-19 vaccination.

2. Community people will have positive attitude towards COVID-19 vaccination

3. Community people will give consent and willingness to collect the necessary data about the knowledge and attitude towards COVID-19 vaccination.

\section{Delimitation of the study:}

The study is delimitated to-

1. 400 subjects as sample for the present study
2. Community people who are residing in and around Dharmada Gram panchayet, Nadia, W.B.

3. Community people who are willing to participate in the study.

\section{METHODOLOGY}

\section{Research approach:}

Descriptive survey approach was adopted for the study.

Research design: cross sectional design was used to carry out the study.

Setting of the study: the investigator selected the community setting in and around Dharmada Gram panchayet Nadia, WB.

Population; the population for the present study was the community people who are residing in the area under Dharma Gram panchayet, Nadia, W.B.

Sample and sample size: Sample size for the present study consists of 400 community people of Dharma Gram panchayet area.

Sampling technique: simple random sampling technique was adopted to collect the data for the present study.

Description of the tools: Data was collected using 3 tools-

Tool 1: Socio-demographic proforma.

Tool 2: Questionnaire on assessment of knowledge regarding COVID-19 vaccination.

Tool 3: Questionnaire on assessment of attitude towards COVID-19 vaccination.

After careful examination of the experts committee consisting of 6 members from the field of Community and Psychiatry, the validity of the tool for the present study was assessed. Some modification was made as per suggestions given by the experts. Reliability of the tool were found to be 0.91 using split half technique and inter-rater method.

To conduct the study necessary consent was taken from the participants.

Ethical permission was also obtained from the concerned authority. Pilot study was conducted among 100 community 
Aditi Karmakar. Assessment of knowledge and attitude towards COVID-19 vaccination among people in selected community of West Bengal.

people to check feasibility and practicability of the study. The study was found to be feasible. The data was tabulated and analyzed using differential and inferential statistics like percentage, mean, standard deviation and chi- square test. The correlation was computed using Pearman's correlation co-efficient ${ }^{[11]}$

\section{RESULT}

Section-A: Description of demographic variables of community people.

\begin{tabular}{|c|c|c|c|c|}
\hline Sl No. & \multicolumn{2}{|c|}{ Variables (Demographic Variables) } & Table-1: $n=400$ & Percentage (\%) \\
\hline \multirow[t]{3}{*}{1.} & \multirow[t]{3}{*}{ Age (in years) } & $18-45$ & 253 & 63.25 \\
\hline & & $46-60$ & 62 & 15.5 \\
\hline & & 61- above & 85 & 21.25 \\
\hline \multirow[t]{2}{*}{2} & \multirow[t]{2}{*}{ Gender } & Male & 225 & 56.25 \\
\hline & & Female & 175 & 43.75 \\
\hline \multirow[t]{5}{*}{3} & \multirow[t]{5}{*}{ Educational status } & No formal Education & 12 & 3 \\
\hline & & Primary & 77 & 19.25 \\
\hline & & Secondary & 82 & 20.50 \\
\hline & & Higher Secondary & 79 & 19.75 \\
\hline & & Graduation and above & 150 & 37.5 \\
\hline \multirow[t]{4}{*}{4.} & \multirow[t]{4}{*}{ Marital Status } & Unmarried & 215 & 53.75 \\
\hline & & Married & 149 & 37.25 \\
\hline & & Separated & 24 & 6 \\
\hline & & Widow & 12 & 3 \\
\hline \multirow[t]{4}{*}{5.} & \multirow[t]{4}{*}{ Religion } & Hinduism & 335 & 83.75 \\
\hline & & Islam & 54 & 13.5 \\
\hline & & Christian & 9 & 2.25 \\
\hline & & others & 2 & 0.5 \\
\hline \multirow[t]{3}{*}{6} & \multirow[t]{3}{*}{ Type of family } & Joint & 169 & 42.25 \\
\hline & & Nuclear & 219 & 54.75 \\
\hline & & Extended & 12 & 3 \\
\hline
\end{tabular}

Table-1 showed that out of 400 subjects, majority (63.25\%) were belonged to the age group between 18-45 years $56.25 \%$ were male, 37055 had completed their graduation, $53.75 \%$ were unmarried, $83.75 \%$ were belong to Hinduism by religion and $54.75 \%$ were belong to nuclear family.

SECTION-B: Description of knowledge and attitude score

Table 2

\begin{tabular}{|l|l|l|l|l|}
\hline $\begin{array}{l}\text { Sl } \\
\text { No. }\end{array}$ & & & Frequency & \% \\
\hline 1 & \multirow{2}{*}{$\begin{array}{l}\text { Knowledge } \\
\text { Score }\end{array}$} & $6-8$ (High) & 114 & 28.5 \\
\cline { 3 - 5 } & & $\begin{array}{l}3-5 \\
\text { (Moderate) }\end{array}$ & 267 & 66.75 \\
\cline { 3 - 5 } & & $0-2$ (Low) & 19 & 4.75 \\
\hline 2 & \multirow{2}{*}{2} & $11-16$ & 393 & 98.25 \\
\cline { 3 - 5 } & & $6-10$ & 6 & 1.5 \\
\cline { 3 - 5 } & & $0-5$ & 1 & 0.25 \\
\hline
\end{tabular}

Table -2 showed that out of 400 subjects, $28.5 \%$ had high knowledge level towards COVID-19 vaccination whereas $66.75 \%$ had moderate knowledge level towards COVID-19 vaccination.

It also showed that out of 400 subjects $98.25 \%$ had high attitude towards COVID-19 vaccination.

SECTION-C: Description related to correlation of knowledge score and attitude scores towards COVID-19 vaccination.

Pearson's correlation coefficient analyzed among collected data between knowledge score and attitude score. It showed negligible correlation $[\mathrm{r}=0.074]$ between knowledge score and attitude score.

SECTION-D: Description related to association between knowledge and attitude score with related socio-demographic variables.

\begin{tabular}{|c|c|c|c|c|c|c|c|}
\hline Variables & & & High & Moderate & Low & Chi value & P value \\
\hline \multirow{3}{*}{ Demographic Variables } & \multirow{3}{*}{ Age (in Year) } & $18-45$ & 76 & 163 & 14 & \multirow[t]{3}{*}{9.23 (NS) } & \multirow[t]{3}{*}{9.43} \\
\hline & & $46-60$ & 11 & 51 & 0 & & \\
\hline & & 61- above & 27 & 53 & 5 & & \\
\hline
\end{tabular}


Aditi Karmakar. Assessment of knowledge and attitude towards COVID-19 vaccination among people in selected community of West Bengal.

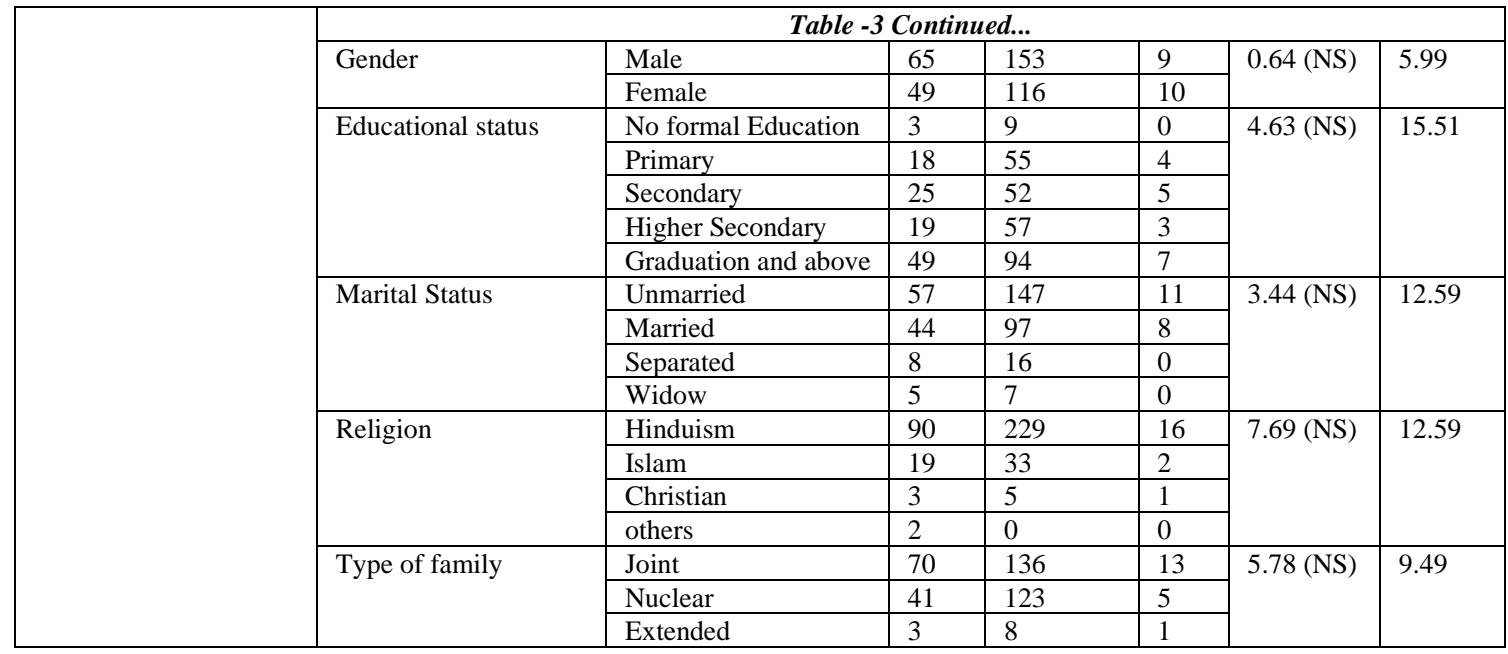

NS = Non-significant, $S=$ significant

Table-4: Attitude Score

\begin{tabular}{|c|c|c|c|c|c|c|c|}
\hline Variables & & & High & Moderate & Low & Chi value & P value \\
\hline \multirow[t]{21}{*}{ Demographic Variables } & \multirow[t]{3}{*}{ Age (in Year) } & $18-45$ & 241 & 10 & 2 & \multirow[t]{3}{*}{2.73 (NS) } & \multirow[t]{3}{*}{9.49} \\
\hline & & $46-60$ & 58 & 4 & 0 & & \\
\hline & & 61- above & 83 & 2 & 0 & & \\
\hline & \multirow[t]{2}{*}{ Gender } & Male & 216 & 7 & 2 & \multirow[t]{2}{*}{2.58 (NS) } & \multirow[t]{2}{*}{5.99} \\
\hline & & Female & 166 & 9 & 0 & & \\
\hline & \multirow[t]{5}{*}{ Educational status } & No formal Education & 12 & 0 & 0 & \multirow[t]{5}{*}{$19.84(\mathrm{~S})$} & \multirow[t]{5}{*}{15.51} \\
\hline & & Primary & 76 & 1 & 0 & & \\
\hline & & Secondary & 81 & 0 & 1 & & \\
\hline & & Higher Secondary & 78 & 1 & 0 & & \\
\hline & & Graduation and above & 135 & 14 & 1 & & \\
\hline & \multirow[t]{4}{*}{ Marital Status } & Unmarried & 201 & 13 & 1 & \multirow[t]{4}{*}{6.57 (NS) } & \multirow[t]{4}{*}{12.59} \\
\hline & & Married & 145 & 3 & 1 & & \\
\hline & & Separated & 24 & 0 & 0 & & \\
\hline & & Widow & 12 & 0 & 0 & & \\
\hline & \multirow[t]{4}{*}{ Religion } & Hinduism & 319 & 14 & 2 & \multirow[t]{4}{*}{0.89 (NS) } & \multirow[t]{4}{*}{12.59} \\
\hline & & Islam & 52 & 2 & 0 & & \\
\hline & & Christian & 9 & 0 & 0 & & \\
\hline & & others & 2 & 0 & 0 & & \\
\hline & \multirow[t]{3}{*}{ Type of family } & Joint & 212 & 7 & 0 & \multirow{3}{*}{$\begin{array}{l}4.44 \\
\text { (NS) }\end{array}$} & \multirow[t]{3}{*}{9.49} \\
\hline & & Nuclear & 158 & 9 & 2 & & \\
\hline & & Extended & 12 & 0 & 0 & & \\
\hline
\end{tabular}

NS = Non-significant, $S=$ significant

\section{DISCUSSION}

From the table -3 it is clear that there is no sufficient relationship among knowledge level regarding COVID-19 vaccination with selected demographic variables.

It is also found that there is negligible correlation among knowledge score and attitude score regarding COVID19 vaccination among the selected community people. So, it can be concluded that knowledge level of the individual does not depend upon their age, educational status, marital status, family type or on type of religion they belong to as well as level of attitude also.

The finding of this study is concordance with the findings revealing that though knowledge about COVID-19 vaccination is inadequate among of people of Malaysia but the majority of the respondent were willing to get vaccinated. This finding can help the authority to plan for future efforts to increase vaccine uptake that may eventually lead to herd immunity against COVID-19 infection ${ }^{[12]}$.

From the table -4 , it is clear that there is only significant relationship found among attitude of the people towards COVID-19 vaccination with educational status of the selected community people. But at the same time, it is also seen that there is no significant relationship with level of attitude and age, sex, marital status, type of family and religion they belong to and level of attitude has less correlation with 
Aditi Karmakar. Assessment of knowledge and attitude towards COVID-19 vaccination among people in selected community of West Bengal.

knowledge level. Similar findings were also observed in a study conducted to assess the attitude towards SARS-COV-2 vaccination among medical and non-medical students. It reveals that the desire to get vaccinated against SARS-COV-2 is more among medical than nonmedical students $(91.99 \%$ vs $59.42 \%)$. The study also explores the social attitudes which is necessarily the first step to optimize vaccination programme and achieving herd immunity towards COVID vaccination $^{[13]}$.

\section{Recommendations:}

I) A comparative study can be done to the residence like rural community versus urban community people.

II) a large number of samples can be included in the study.

III) other variables like perception stress etc. can be included in the study.

\section{Nursing implication:}

The finding of the present study reflects that there is negligible association between knowledge level and attitude score towards COVID-19 vaccination among general population of West Bengal. In order to impose knowledge and attitude immediately "Information Education Communication (IEC)” programmes need to be initiated.

\section{CONCLUSION}

This preliminary observation suggest that mass health educational programme need to be started to increase the knowledge and attitude towards COVID-19 vaccination.

Acknowledgement: None

Conflict of Interest: None

Source of Funding: None

Ethical Approval: Approved

\section{REFERENCES}

1. Islam, S. Md, Siddique A B, Akter, R. et al. : Knowledge, attitude and perception towards COVID-19 Vaccination: a cross sectional community survey in Bangladesh, BMC Public Health, 2021, 1851.

2. Cucinotta D, Vanelli M : WHO declares Covid -19 a Pandemic. Acta Biomedica Atenei Parm 2020, 91: 157-160. Doi: 10,23750/abm.vqlil.9397.

3. http://www.worldometus.info >countries where covid-19 has spread world meter.

4. Andrew M A , Areekal B et al. : First confirmed case of covid-19 infection in India: A case report, Indian J Med Res 2020, 151(5): 490492.

5. Chyan EY-Y, Cheng CK-Y, Tam GC-H, Hiang Z, Lee P Y: Willingness of future A/H7N9 influenza vaccine uptake: A cross- sectional study in Hong Kong Community Vaccine.2015, 33: 47374740. Doi : 10.101 6/j vaccine 2015.

6. WHO Covid vaccine tracker last updated $\quad 5^{\text {th }} \quad$ November,2021. http://covid-19 tracker vaccines.org>

7. http://www.mygov.in : Covid -19 vaccine information get updates on covid -19 -mygov.in

8. http://www.mygov.in : Check updates on Covid -19 statewise lockdown status -mygov.in

9. Lazarus J V, Ratzan S, Palayew A et al: Hesitant or not? A global survey of potential acceptance of COVID-19 vaccine. Med Rxiv. 2020doi: 10.1101/2020.08.23.20180307.

10. Lin Y HUZ, Zhao Q, Alias H, Danase M, Wong, L P: understanding covid-19 vaccine demand and hesitancy : A nationwide online survey in China. PLOs NeglTrop Dis.2020,14:e 0008961 doi 10.1371/Journal Pntd 0008961

11. Polit Denise F, Bech Cheryl T : Essentials Nursing Research apprising evidence for Nursing practice. $8^{\text {th }}$ edition, 2013, Lippincott Williams \& Wilkins. Page 200-220.

12. Mohamed N A, Solehan H M, Mohd Rani MD, Ithnin M, Che Isanak C I: 
Aditi Karmakar. Assessment of knowledge and attitude towards COVID-19 vaccination among people in selected community of West Bengal.

Knowledge acceptance and perception on Covid-19 vaccine among Malaysians, 2021: A web-based survey PLOS OIVB 16(8).

13. Szmyd B, Bartoszek A, Karuga FF, Staniecka K, Błaszczyk M, Radek M. Medical Students and SARS-CoV-2 Vaccination: Attitude and Behaviors. Vaccines (Basel). 2021 Feb 5;9(2):128. doi: 10.3390/vaccines9020128. PMID: 33562872; PMCID: PMC7915119.

How to cite this article: Karmakar A. Assessment of knowledge and attitude towards COVID-19 vaccination among people in selected community of West Bengal. International Journal of Research and Review. 2021; 8(12): 638-643. DOI: https://doi.org/10.52403/ijrr.20211278 